\title{
Understanding of mineral change mechanisms in coal mine groundwater reservoir and their influences on effluent water quality: a experimental study
}

\author{
Kai Zhang ${ }^{1,2}$ (1) $\cdot$ Huifang $\mathrm{Li}^{1,2} \cdot$ Jiaming Han ${ }^{1,2} \cdot$ Binbin Jiang ${ }^{1,2} \cdot$ Ju Gao $^{1,2}$
}

Received: 3 December 2019/Revised: 8 July 2020/ Accepted: 9 September 2020/Published online: 26 September 2020

(C) The Author(s) 2020

\begin{abstract}
This paper presents results of an experimental study to characterize the law of mineral change of fallen rock in coal mine groundwater reservoir ant its influence on water quality. The minerals of the underground reservoir of Daliuta Coal Mine is taken as the research object. Simulation experiments were designed and conducted to simulate water-rock action in the laboratory. The mineral composition was analyzed by X-ray diffractometer (XRD), the surface morphology of the mineral was analyzed by scanning electron microscope (SEM), and the specific surface area, total pore volume and average pore diameter of the mineral were measured by fast specific surface/pore analyzer (BET). The experimental results show that the sandstone and mudstone in the groundwater reservoir of Daliuta Coal Mine account for $70 \%$ and $30 \%$, respectively. The pore diameter is $15.62-17.55 \mathrm{~nm}$, and pore volume is $0.035 \mathrm{cc} / \mathrm{g}$. Its pore structure is a key factor in the occurrence of water-rock interaction. According to the water-rock simulation experiment, the quartz content before the water-rock action is about $34.28 \%$, the albite is about $21.84 \%$, the feldspar is about $17.48 \%$, and the kaolinite is about $8.00 \%$. After the water-rock action, they are $36.14 \%, 17.78 \%, 11.62 \%$, and $16.75 \%$, respectively. The content of albite and orthoclase is reduced while the content of kaolinite is increased, that is, the $\mathrm{Na}^{+}$content becomes higher, and the $\mathrm{Ca}^{2+}$ and $\mathrm{Mg}^{2+}$ contents become lower. This research builds a good theoretical foundation for revealing the role of water and rock in underground coal reservoirs.
\end{abstract}

Keywords Coal mine underground reservoir $\cdot$ Fallen rock $\cdot$ Water-rock interaction $\cdot$ Rock composition

\section{Introduction}

After coal mining, a large number of gobs are formed at different mining levels. With the end of the disturbance of overburden strata, the gob tends to be stable and a large void space is formed, which provides space for mine water storage due to the impermeability of the floor. The underground reservoir is a water conservancy project with

Kai Zhang

zhangkai@cumtb.edu.cn

1 School of Chemical and Environmental Engineering, China University of Mining and Technology,

Beijing, Beijing 100083, China

2 State Key Laboratory of Water Resource Protection and Utilization in Coal Mining, Beijing 102211, China the emphasis on storage capacity, which is formed by the gap between the rock and soil as the water storage space. It is a systematic project of artificial recharge of groundwater, underground storage of water resources, and human activities of exploitation (Du et al. 2008). Since coal mines are usually located in a region where water resources are scarce or severely deficient, the use of underground reservoir is of great significance for water resources protection and ecological environment protection (Chen 2018). Compared with surface reservoirs, groundwater reservoirs have the advantages of high safety, low investment, no land occupation, and no siltation (Lan et al. 2010).

The problem of water quality in groundwater reservoirs is mainly the impact of recharged water on groundwater environment, the impact of groundwater environment on recharged water sources, and the changes in water quality 
of recharged water in the process of groundwater storage (Wang et al. 2018). The change of water quality of recharge water can directly affect the efficiency and operating cost of groundwater purification, and service life of groundwater reservoir (Du et al. 2018). The research of Liu (2016) shows that the changed ion content of groundwater and weakened rocks, can be powerful evidence for the process of water-rock interaction. Therefore, not only the water source prediction, site storage capacity, dam construction, and safety of coal mine groundwater reservoir need to study, but also the control of water quality of coal mine groundwater reservoir.

Due to changes in groundwater circulation patterns and water-rock interactions, the hydrogeochemical environment in the mining area has undergone tremendous changes (Feng et al. 2019a, b). Gu (2015) found through simulation experiments that the reduction of suspended solids, calcium ions, and COD concentration in mine water is related to the solid-liquid coupling effect of the fallen rock and liquid. Hu et al. (2016) found that mine water immersion has the greatest impact on the microstructure of mudstone. They also explained that the reason may be that the chemical environment is different. On the one hand, the ion environment in the mine water is complex and then content of ion is high, which causes a large amount of ion exchange between the micro-crack and the solution, which will destroy some of its chemical bonds and destroy its microstructure. On the other hand, the $\mathrm{pH}$ and $\mathrm{Eh}$ of the mine water itself promoted the destruction of micro-fractures in the mudstone. Li et al. (2008) explored the waterrock interaction mechanism of mine water in the process of saturated coal rock infiltration. During the infiltration process of the mine water, the total hardness, $\mathrm{SO}_{4}{ }^{2-}$, and $\mathrm{Cl}^{-}$are first adsorbed by the rock at the beginning. Soon after the adsorption equilibrium is reached, dissolution, resolution, and ion exchange occur, and the dissolution rate is large at the beginning and then gradually decreases until it reaches zero. Lin et al. (2012) analyzed the changing trend of the main solute components of groundwater and the related water-rock reaction during the artificial recharge process through indoor simulation experiments. The results show that the main ionic components of groundwater are mainly affected by mixing, cation exchange adsorption, and dissolution of aquifer mineral facies (calcite, dolomite, and potassium feldspar). As a natural water storage container, groundwater reservoir can solve the problem of mine water supply and drainage, sewage treatment, flood prevention, environmental protection, and energy conservation and emission reduction if reasonably utilized. To ensure mine water resources safe and efficiently utilized, water-rock interaction is one of the most important factors. Studying the composition of the fallen roof minerals accumulated in the groundwater reservoir and its changes under the action of water-rock is the key point to understand the purification mechanism of the underground mine reservoir and control the water quality of the underground reservoir.

Basic geology and mineral resources, groundwater environment evolution and global changes, migration of trace elements in aqueous systems, transformation and enrichment, effects of water chemistry and rock mechanics, and groundwater pollution control and restoration are current research focuses in the field of rock interactions, (Shen et al. 2012; Wang et al. 2015). Goren et al. (2011) found out through indoor simulation experiments that the main controlling factors of artificial recharged wastewater and calcareous sandstone sedimentary water are cation exchange and $\mathrm{CaCO}_{3}$ dissolution. Zhang et al. (2011) conducted experiments to simulate interaction between different proportions of wastewater and carbonate rocks and the analysis shows that heavy metal salt solution has a dissolution effect on carbonate rock, and can produce secondary minerals. Deng et al. (2019) designed an indoor immersion-air-drying cycle test to monitor water pressure rise and fall and used SEM electron microscopy to analyze sandstone microscopic structure. The results show that the sandstone surface of the first six immersion-air-drying tests is particularly effective, and the sandstone surface develops from dense to irregular honeycomb structure. Gu (2018) studied the fracturing fluid-shale interaction mechanism in shale gas reservoirs during hydraulic fracturing through laboratory experiments and hydrogeochemical software simulation. Wang (2017); through the combination of theoretical analysis, laboratory test, and numerical analysis, studied the water degradation effect on rock and the mechanism of rock deformation and failure, and established a constitutive model of water-bearing rock. Zhu (2017) independently developed the rock gaseous water adsorption test system, studied the gaseous water adsorption characteristics of the sample, and combined the SEM scanning experiment and X-ray diffraction experiment to analyze the influence of clay minerals and voids and fissures on the adsorption of gaseous water.

These research results show that in the role of water and rock, the change of lithofacies is crucial to the composition of water bodies. The groundwater-rock interaction simulation is mostly completed by indoor simulation experiments. The characterization of rocks is mostly by electron microscopy and X-ray diffraction. At present, most scholars' research focuses on the study of underground aquifers in conventional groundwater or artificial recharge areas. Research on the water-rock interaction in coal mine groundwater reservoirs is rare. The law of the change of the mineral composition of the fallen rock and the water quality of coal mine groundwater reservoir has not been systematically analyzed. 
This paper focuses on studying the fallen rock in the underground reservoir of Daliuta Coal Mine. Based on previous studies on the geology and hydrogeology of the study area, this research is to determine the mineral composition of the fallen rock sample and the characteristics of the water quality of the inflow and outflow of the coal mine groundwater reservoir. Simulation experiments are designed to simulate the long-term contact of rock samples of different lithologies with mine water under coal mine conditions. The change of rock mineral composition and its structure are analyzed, and then its impact on the water quality in the groundwater reservoir. This research lays a solid foundation for the research on key technologies of mine water recycling in the subsequent underground reservoirs, the regulation of water resources in mining areas, and the protection of water supply and environmental impact assessment of mine groundwater.

\section{Materials and methods}

\subsection{Overview of the study area}

The Daliuta Coal Mine in Shendong Mining Area is located in the northwest of Shenmu County, Yulin City, Shaanxi Province. The geographical coordinates are: N39 $13^{\prime} 53^{\prime \prime}-39^{\circ} 21^{\prime} 32^{\prime \prime}$ and E110 $12^{\prime} 23^{\prime \prime}-110^{\circ} 22^{\prime} 54^{\prime \prime}$. The area of Daliuta Coal Mine is approximately $126.80 \mathrm{~km}^{2}$.

The depth of the groundwater reservoir of Daliuta Coal Mine is about $130 \mathrm{~m}$ from the surface. Three underground reservoirs of No. 1, 2, and 3 were built using the horizontal $2^{-2}$ coal seam gob, and two recycling diverticulum were built in the second level $5^{-2}$ coal gob, and No. 4 underground reservoir is being constructed. At present, only the water of the aquifer is replenished, and the sewage is not recharged (Chen et al. 2016).

Through the simulation experiments and on-site measurement, the water storage coefficient of the underground reservoir of Daliuta Coal Mine is 0.15-0.20. The current water storage capacity of No. 1, 2 and No. 3 Reservoir is about $3.36 \times 10^{6} \mathrm{~m}^{3}, 1.93 \times 10^{6} \mathrm{~m}^{3}$ and $1.82 \times 10^{6} \mathrm{~m}^{3}$, respectively (Chen et al. 2016).

\subsection{Sample collection and preservation}

Since the $2^{-2}$ coal seam has been mined and three underground reservoirs have been built, it is impossible to collect rock samples that have fallen into the underground reservoirs No. 1, No. 2 and No. 3. To obtain a similar sample, the mineral sample of the $5^{-2}$ coal seam falling roof was collected, and the experimental mineral composition was subsequently constructed according to the $2^{-2}$ coal seam borehole data. The locations of collection points of the water inflow and outflow of the coal mine underground reservoir is shown in Fig. 1. According to the actual situation of the site, select the sampling points allowed by the conditions. One water inlet and two water outlets are selected in No. 1 underground reservoir of seam $2^{-2}$, as 22,406, 400, 406, respectively. And No. 2 underground reservoir of seam $2^{-2}$ is the same, as 201, 608, 615, respectively. Fissure water and water samples of inlet $5^{-2}$ in No. 2 underground reservoir are selected in $5^{-2}$ coal seam. Sampling scheme design and technology are strictly in accordance with the industry standard "Water Quality Sampling Technical Guidance" (HJ 494-2009) and "Water Quality Sampling Scheme Design Technical Regulations" (HJ 495-2009). The $\mathrm{pH}$ was measured on-site. $\mathrm{Na}^{+}, \mathrm{Mg}^{2+}$, $\mathrm{K}^{+}, \mathrm{Ca}^{2+}$, suspended solids (SS), Total dissolved solids (TDS), Chemical Oxygen Demand (COD), $\mathrm{Cl}^{-}, \mathrm{SO}_{4}{ }^{2-}$, and $\mathrm{F}^{-}$were determined in the laboratory after pretreating the water sample and preserved in a dark place at $1-5{ }^{\circ} \mathrm{C}$.

One water inlet and two water outlets are selected in No. 1 underground reservoir, as $22,406,400,406$, respectively. And No. 2 underground reservoir is the same, as 201, 608, 615 , respectively.

\subsection{Simulation experiment design and parameter selection}

According to the drilling log of the mine area where the underground coal reservoir is located and the rock samples taken at the site, the fallen rock in the underground reservoir is mainly sandstone and mudstone. Therefore, fine sandstone and mudstone with parallel bedding are selected as the main research objects. According to the analysis of Zhang et al. (2013) of the 12,201 gob, Laoliupan and 22,613 gob in Daliuta Coal Mine, the average filter height is $3.50 \mathrm{~m}$, the distance between the average pumping hole and the water injection hole is $1100 \mathrm{~m}$, the average slump rock fracture maximum block size (diameter) is $600 \mathrm{~mm}$, and the water storage coefficient (Chen 2016) is between 0.15 and 0.25 .

The water-rock sample was prepared in a $1000 \mathrm{~mL}$ beaker which was placed in an isothermal chamber. The two rock samples, fine sandstone and mudstone with parallel bedding, were crushed to $2-12 \mathrm{~mm}$ with a jaw crusher and then mixed with the mine water sample with the waterrock mass ratio of about 1:2. To ensure that the experimental environment is close to the operating conditions of the coal mine groundwater reservoir, the temperature was controlled as $25{ }^{\circ} \mathrm{C}$ (micro-reducing condition). The experiment setup after connecting agitator is shown in Fig. 2. One group was set as control experiment and the other group was set of blank control experiments. After soaking in the mine water for 47 days (Tang et al. 2018), 


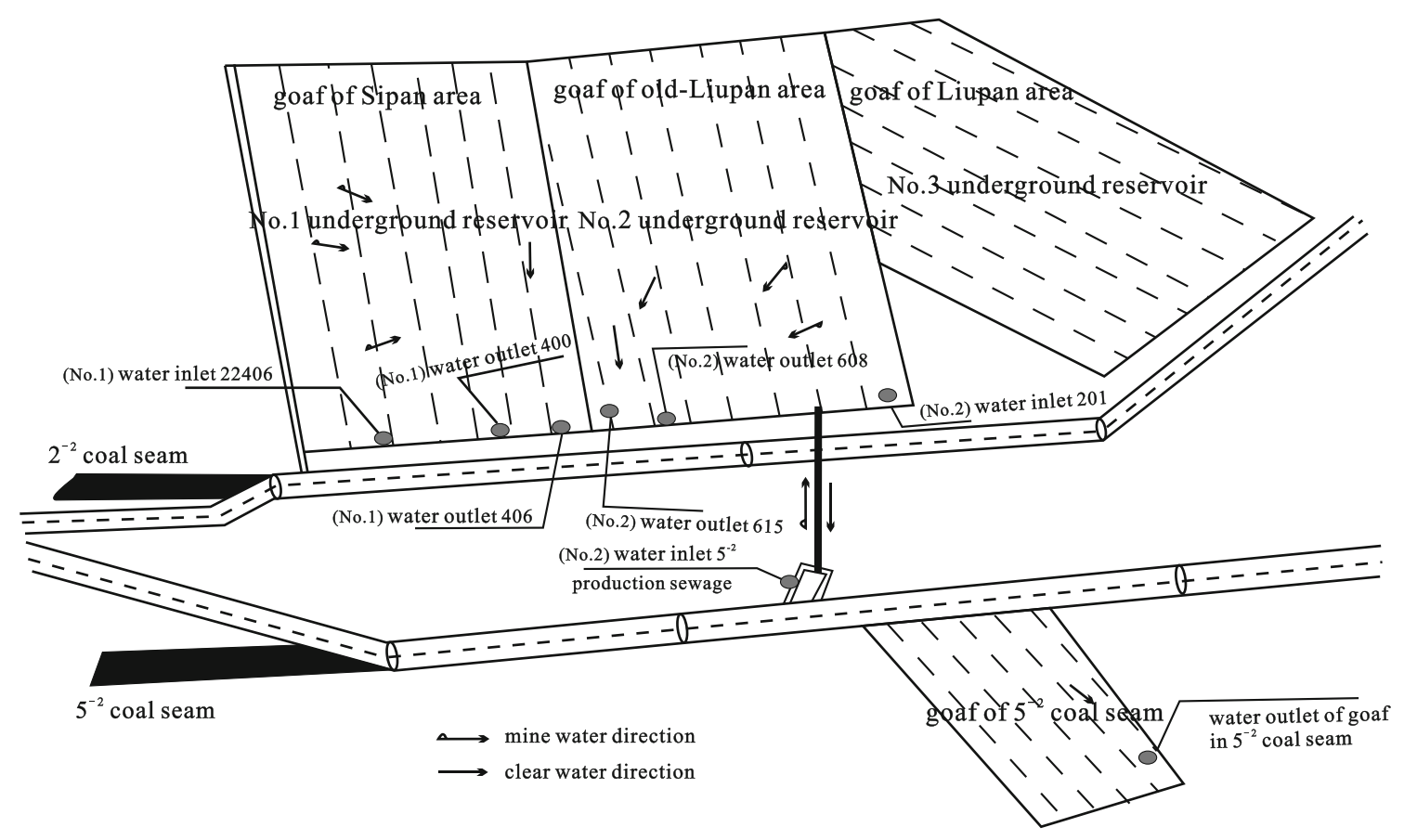

Fig. 1 Water sample collection location

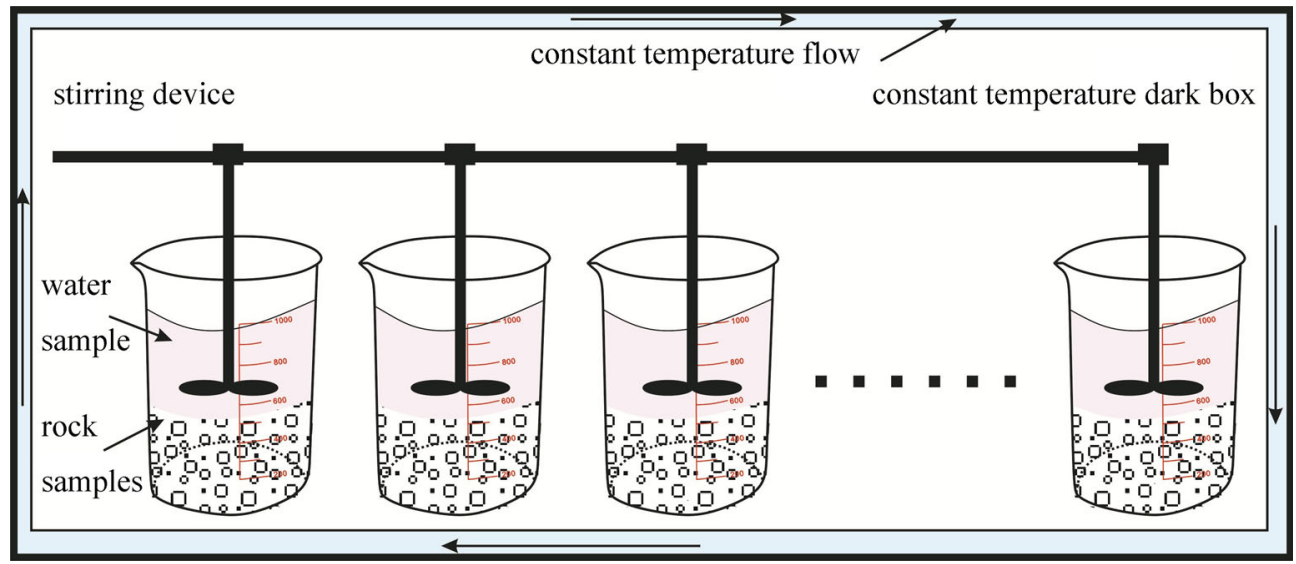

Fig. 2 Simulation experiment setup for water-rock interaction in groundwater reservoir

the rock samples after the immersion were taken out and ground to about 300 mesh for testing.

\subsection{Sample testing and analysis}

The rock sample collected in the Daliuta Coal Mine and the sample after the simulation test were ground to about 300 mesh. The D/max-2500v/pc type X-ray diffractometer (XRD) (Cu target, $\mathrm{K} \alpha$ radiation, step size of $0.02^{\circ}$, power of $40 \mathrm{kV}, 150 \mathrm{~mA}$, continuous scanning) produced by Rigaku Corporation of Japan was used for mineral composition analysis. The following test conditions were used: $2 \theta$ angle range is $5^{\circ}-70^{\circ}$ and scanning speed is $4 \% \mathrm{~min}$. Using ultrasonic high-resolution thermal field emission scanning electron microscope (SEM) of Japan JSM-7610F (magnification of 0.25 to 1 million times), the rock samples which are crushed and screened to less than $75 \mu \mathrm{m}$ are magnified to 3-30 $\mu \mathrm{m}$. The ASAP 2020 M Rapid Specific Surface/Pore Analyzer (BET) was used to determine the specific surface area, total pore volume, and average pore size of the two types of rock samples, parallel layered mudstone and fine sandstone in Daliuta Coal Mine. The determination of specific surface area is based on the BET test method, and the pore volume and pore size distribution utilize the BJH theory. The instrument has a specific surface area measurement range of $0.005 \mathrm{~m}^{2} / \mathrm{g}$ to infinity, a pore size distribution measurement range of 0.35 to $500 \mathrm{~nm}$ (using $\mathrm{H}-\mathrm{K}$ or DA analysis), and a minimum pore 
volume analysis of $0.0001 \mathrm{cc} / \mathrm{g}$ (using $\mathrm{H}-\mathrm{K}$ or $\mathrm{DA}$ analysis).

According to the "groundwater quality inspection method" (DZ/T0064-1993) (Ministry of Geology and Mineral Resources of the People's Republic of China 1994), the pH of the water sample was measured by portable water quality multi-function parameter tester onsite immediately after the sample was collected, and the remaining water quality indicators were tested in laboratory. Part of the water sample was sealed and stored for subsequent experimental analysis after filtered with a $0.45 \mu \mathrm{m}$ filter. COD was determined by potassium dichromate titration. The water sample was oxidized by potassium dichromate standard solution. After heating and refluxing, the standard solution of ammonium ferrous sulfate was used to drop back. SS and TDS were determined by gravimetric method. Fully mixed $100 \mathrm{~mL}$ of water sample for suction filtration, washed them with $10 \mathrm{~mL}$ of distilled water for three times continuously, and weighed the filtrate and membrane respectively to obtain the TDS and SS. $\mathrm{CO}_{3}{ }^{2-}$ and $\mathrm{HCO}_{3}^{-}$were determined by titration (Liu 1981). Added drop phenolphthalein indicator and titrated with $0.05 \mathrm{~mol} / \mathrm{L} \mathrm{HCl}$ standard solution until the red color disappeared. Then added methyl orange indicator and titrated with $\mathrm{HCl}$ until the solution changes from yellow to orange. Anions such as $\mathrm{Cl}^{-}, \mathrm{SO}_{4}{ }^{2-}, \mathrm{NO}_{3}^{-}$, and $\mathrm{F}^{-}$are determined by ion chromatography (IC) (Ministry of Environmental Protection of the People's Republic of China 2016). The following chromatographic conditions were used: concentration of sodium carbonate of $0.0018 \mathrm{~mol} / \mathrm{L}$, concentration of sodium bicarbonate of $0.0017 \mathrm{~mol} / \mathrm{L}$, injection volume of $25 \mu \mathrm{L}$, eluent flow rate of $1.0-2.0 \mathrm{~mL} / \mathrm{min}$, and regenerant flow rate determined according to eluent flow rate. Conventional cations such as $\mathrm{K}^{+}, \mathrm{Na}^{+}, \mathrm{Ca}^{2+}, \mathrm{Mg}^{2+}$ were determined by inductively coupled plasma mass spectrometry (ICP-MS) (Ministry of Geology and Mineral Resources of the People's Republic of China 2015).

Determine the composition of minerals in a sample was conducted using Jade 6.0 (MDI, Livermore, CA, USA) in conjunction with the material standard powder diffraction data (PDF 2004) provided by the Powder Diffraction Consortium International Data Center (JCPDS-ICDD).

\section{Results and discussion}

\subsection{Analysis of rock formation and water quality in coal mine groundwater reservoir}

It can be seen from Table 1 that the influent and effluent of coal mine underground reservoir is neutral or alkaline, the main cations in the water sample were $\mathrm{Na}^{+}, \mathrm{Ca}^{2+}$ and the average content was $168.27 \mathrm{mg} / \mathrm{L}$ and $158.61 \mathrm{mg} / \mathrm{L}$; and the main anions were $\mathrm{Cl}^{-}$and $\mathrm{SO}_{4}{ }^{2-}$, the average content was $293.16 \mathrm{mg} / \mathrm{L}$ and $344.93 \mathrm{mg} / \mathrm{L}$, respectively. Compared with the influent, the suspended solids in the effluent are obviously reduced, the total hardness is reduced, $\mathrm{Na}^{+}$ and $\mathrm{Cl}^{-}$increase, and $\mathrm{COD}, \mathrm{Ca}^{2+}, \mathrm{Mg}^{2+}, \mathrm{HCO}_{3}^{-}$and $\mathrm{SO}_{4}{ }^{2-}$ decrease. The change of $\mathrm{K}^{+}$and $\mathrm{Mg}^{2+}$ is not obvious because of the lower content. According to Shukarev's nomenclature, the type of water chemistry changes from influent type 36- $\mathrm{A}\left(\mathrm{SO}_{4}{ }^{2-} \cdot \mathrm{Cl}^{-}-\mathrm{Ca}^{2+}\right)$ to effluent type 42-A $\left(\mathrm{SO}_{4}{ }^{2-}\right.$. $\left.\mathrm{Cl}-\mathrm{Na}^{+}\right)$(Han et al. 2016; Zhang et al. 2019. Referring to the "Standard for Groundwater Quality" (GB/ T14848-2017), although the water quality of influent and effluent in groundwater reservoir generally conforms to the quality standard for class $\mathrm{V}$ groundwater, compared with the influent quality, the effluent quality has been significantly improved.

Ma and Wang (2017) and Xu et al. (2019) believed that water-rock interaction is the dominant feature of water chemistry in the study area, and the water body ions are significantly affected by water-rock interaction. According to the change of hydrochemical characteristics of water, it indicates that there is water-rock interaction in coal mine underground reservoir, and the hydrochemical characteristics of effluent water are closely related to the fallen rocks in coal mine groundwater reservoir. Therefore, further study of the mineral composition in the groundwater reservoir is a necessary step to reveal the water-rock interaction.

The minerals in the underground reservoir of coal mine mainly come from the collapse of the roof and its overlying strata. Thus, the composition and distribution characteristics of the overlying strata are the basis for studying the mineral composition in the reservoir. The average buried depth of the groundwater reservoirs in No. 1 and No. 2 of Daliuta Coal Mine is 93.57-104.09 m, with an average of $98.83 \mathrm{~m}$. The distance between the groundwater reservoirs and Quaternary strata is $62.56-66.80 \mathrm{~m}$, with an average of $64.68 \mathrm{~m}$ (Chen et al. 2016; Gu 2012; Li et al. 2017) (Fig. 3). The overlying lithology of No. 1 underground reservoir is mainly sand-mud interbedded layer, with multiple coal-bearing lines. The thickness of mudstone accounts for about $27 \%$ of the total thickness of the overlying strata of No. 1 groundwater reservoir, and the thickness of sandstone accounts for about $72 \%$. The thickness of the $2^{-2}$ coal seam of No. 1 groundwater reservoir is $4.21 \mathrm{~m}$, and the rock layers adjacent to the upper part are interbedded with siltstone and medium sandstone, respectively, with a total thickness of $22.40 \mathrm{~m}$ (Fig. 3a). The distribution of No. 2 groundwater reservoir is similar to that of No. 1, with mudstone thickness accounting for about $30 \%$ and sandstone thickness accounting for about $70 \%$. The thickness of the $2^{-2}$ coal 
Table 1 Chemical analysis of coal mine groundwater reservoir (mg/L)

\begin{tabular}{llllllllllll}
\hline Sampling point & $\mathrm{COD}$ & $\mathrm{SS}$ & Turbidity & $\mathrm{pH}$ & $\mathrm{Na}^{+}$ & $\mathrm{K}^{+}$ & $\mathrm{Ca}^{2+}$ & $\mathrm{Mg}^{2+}$ & $\mathrm{Cl}^{-}$ & $\mathrm{SO}_{4}^{2-}$ & $\mathrm{HCO}_{3}^{-}$ \\
\hline No. 1 Reservoir inlet 22,406 & 56.34 & 636.27 & - & 7.05 & 131.98 & 0.10 & 172.76 & 10.54 & 289.22 & 367.34 & 118.79 \\
No. 1 Reservoir outlet 400 & 32.78 & - & 102.00 & 6.98 & 174.03 & 1.52 & 126.45 & 23.46 & 287.10 & 330.24 & 107.86 \\
No. 1 Reservoir outlet 406 & & - & 96.00 & 7.15 & 172.85 & 0.10 & 138.40 & 9.68 & 320.34 & 321.20 & 109.39 \\
No. 2 Reservoir inlet 5-2 & \multirow{2}{*}{49.64} & 2496.60 & - & 7.06 & 137.48 & 0.10 & 213.56 & 0.13 & 300.26 & 387.12 & 117.47 \\
No. 2 Reservoir inlet 201 & & 560.81 & - & 7.15 & 138.39 & 0.10 & 168.47 & 14.90 & 266.54 & 356.23 & 120.01 \\
No. 2 Reservoir outlet 615 & 27.56 & - & 76.00 & 8.22 & 204.37 & 0.10 & 151.51 & 0.00 & 310.12 & 310.80 & 111.68 \\
No. 2 Reservoir outlet 608 & & - & 121.00 & 7.04 & 218.78 & 0.10 & 139.11 & 1.12 & 278.56 & 341.56 & 109.89 \\
Fissure water & 25.32 & - & 78.00 & 7.15 & 201.09 & 0.10 & 140.31 & 1.44 & 268.30 & 315.67 & 118.93 \\
\hline
\end{tabular}

seam of No. 2 groundwater reservoir is $4.71 \mathrm{~m}$, and the rock layers adjacent to the upper part are mudstone, siltstone and fine sandstone, respectively, with total thicknesses of $2.46 \mathrm{~m}, 1.14 \mathrm{~m}$ and $5.39 \mathrm{~m}$, respectively, totaling $8.99 \mathrm{~m}$ (Fig. 3b). In summary, the overlying lithology of coal mine groundwater reservoirs in the study area is mainly sandstone, including siltstone, fine sandstone and medium sandstone, accounting for about $70 \%$; followed by mudstone, including mudstone and carbonaceous mudstone, accounting for about $30 \%$.

Fu et al. (2018) studied in the Huai'nan Xinji mining area and found that $\mathrm{Cl}^{-}$and $\mathrm{Na}^{+}$are the main sources of TDS in sandstone water, $\mathrm{Na}^{+}, \mathrm{Ca}^{2+}, \mathrm{Mg}^{2+}$, and $\mathrm{Cl}^{-}$are related, $\mathrm{Na}^{+}$and $\mathrm{Ca}^{2+}, \mathrm{Mg}^{2+}$ have alternating adsorption, and $\mathrm{Na}^{+}$and $\mathrm{Cl}^{-}$may be from the dissolution of rock salt. Yan et al. (2014) used the tap water to soak the mudstone of the Xinzhuang Coal Mine and found that the largest relative change is $\mathrm{S}$ and $\mathrm{CaO}$. Studies of Zhang et al. (2018) have shown that the lithology of the 10 coal seams floor of Haishu Mine is light gray fine sandstone and dark gray-grey black mudstone and siltstone interbed, and the roof is light gray medium-fine quartz sandstone. The ion content of sandstone water in the roof and floor is obviously different. The hydrochemistry type of coal measures sandstone in the floor is mainly $\mathrm{Ca}^{2+} \cdot \mathrm{Mg}^{2+}-\mathrm{SO}_{4}{ }^{2-}$, and the hydrochemistry type coal measures sandstone in the roof is mainly $\mathrm{HCO}_{3}^{-} \cdot \mathrm{Cl}^{-}$. The water quality has changed obviously, and the change is related to the mineral properties of rocks, that is, the water quality is controlled by the fallen rocks in the underground reservoir. Therefore, the concentration of major ions in the waters of the study area has changed, and the water quality has been significantly improved. It is speculated that the water-rock action of the reservoir water and the fallen rock changes the ion content of the water.

\subsection{Characteristics Analysis of Mineral Structure of Coal Mine Groundwater Reservoir}

In order to further analyze the main sites of water-rock reaction and the influence of mineral surface changes on water-rock interaction, the morphology was characterized by scanning electron microscopy and the specific surface area and pores of rock samples were determined by nitrogen adsorption. The results are shown in Figs. 4, 5 and Table 2.

Before the action of water-rock, the sandstone and mudstone surface showed a flocculent porous structure with layered silicate structure and flaky kaolinite (Fig. 4). After the mine water passes through the reservoir sedimentation and water-rock action, the mineral surface structure became dense and the porous structure disappears (Fig. 5). Due to the development of pores and micro-cracks in clay minerals, the surface area increases, which enhances its adsorption capacity. Moreover, the granularity of the fallen sandstone in the underground reservoir of the coal mine is good, and the particles are closely arranged, which has a good filtration and adsorption effect on the mine water. Engineering practice (Gu 2015; Chen et al. 2016; Cao et al. 2014) and Table 1 show that with the increase of water-rock action time, the minerals on the rock surface are coupled with the mine water, the SS of the groundwater reservoir is greatly reduced, the COD is slightly reduced, and the water quality is changed. The content of albite and some clay minerals is reduced, so that the adsorption capacity of the rock surface is slowly weakened. The above analysis indicates that the mineral surface structure is the main site of adsorption, transition and water-rock action, and it is also the key to water purification. The mineral surface structure and pore distribution change after waterrock interaction, which affects the subsequent purification effect of mine water.

The specific surface area of the rock sample was $7.18-9.93 \mathrm{~m}^{2} / \mathrm{g}$ with a mean of $8.56 \mathrm{~m}^{2} / \mathrm{g}$. The pore 


\begin{tabular}{|c|c|c|c|}
\hline $\begin{array}{c}\text { rock } \\
\text { stratum }\end{array}$ & lithology & thickness & depth \\
\hline $\begin{array}{c}\text { medium } \\
\text { sandstone }\end{array}$ & $\therefore \quad .$. & $\begin{array}{l}3.27 \\
0.15\end{array}$ & $\begin{array}{r}\frac{49.55}{50.10} \\
\end{array}$ \\
\hline $\begin{array}{l}\text { mudstone } \\
\text { medium }\end{array}$ & $\begin{array}{ll} & = \\
\therefore & \cdots\end{array}$ & 3.73 & 53.83 \\
\hline $\begin{array}{l}\text { sandstone } \\
\text { mudstone }\end{array}$ & $\overline{E=}$ & 0.60 & 54.43 \\
\hline sandy mudston & {$[\because . . \cdots$} & 0.80 & 55.23 \\
\hline $\begin{array}{l}\text { medium } \\
\text { sandstone }\end{array}$ & $\begin{array}{l}-\cdot-\cdots \\
\cdots \cdots \cdots\end{array}$ & 5.70 & 60.93 \\
\hline mudstone & $\frac{--}{--1}$ & 1.50 & 62.43 \\
\hline fine sandstone & -7 & 1.99 & 64.42 \\
\hline mudstone & & 4.64 & 69.06 \\
\hline $\begin{array}{c}\text { medium } \\
\text { sandstone }\end{array}$ & & 3.44 & 72.50 \\
\hline siltstone & $\cdots$ & 1.00 & 73.50 \\
\hline $\begin{array}{c}\text { medium } \\
\text { sandstone }\end{array}$ & & 5.60 & 79.10 \\
\hline siltstone & & 10.26 & 89.36 \\
\hline $2^{-2}$ coal seam & & 4.21 & 93.57 \\
\hline
\end{tabular}

(a) No.1 underground reservoir

\begin{tabular}{|c|c|c|c|}
\hline $\begin{array}{c}\text { rock } \\
\text { stratum }\end{array}$ & lithology & thickness & depth \\
\hline sandy mudston & $E \cdot-\cdot$ & 5.20 & 63.71 \\
\hline fine sandstone & $F \cdot-\cdot-\cdot$ & 1.33 & 65.04 \\
\hline $1^{-2}$ coal seam & & 3.99 & 69.03 \\
\hline fine sandstone & & 3.05 & 72.08 \\
\hline mudstone & -- & 3.26 & 75.34 \\
\hline siltstone & ……..... & 4.44 & 79.78 \\
\hline mudstone & --- & 2.87 & 82.65 \\
\hline siltstone & $\ldots \ldots \ldots \ldots$ & 1.62 & 84.27 \\
\hline mudstone & $=--$ & 1.25 & 85.52 \\
\hline siltstone & $\cdots \cdots$ & 4.87 & 90.39 \\
\hline fine sandstone & & 5.39 & 95.78 \\
\hline siltstone & …...... & 1.14 & 96.92 \\
\hline mudstone & --- & 2.46 & 99.38 \\
\hline $2^{-2}$ coal seam & & 4.71 & 104.09 \\
\hline
\end{tabular}

(b) No.2 underground reservoir

Fig. 3 Drilling log of No. 1 and No. 2 Underground Reservoir

volume was $0.03-0.04 \mathrm{cc} / \mathrm{g}$, with the average value of $0.035 \mathrm{cc} / \mathrm{g}$. The pore size distribution was $15.62-17.55 \mathrm{~nm}$

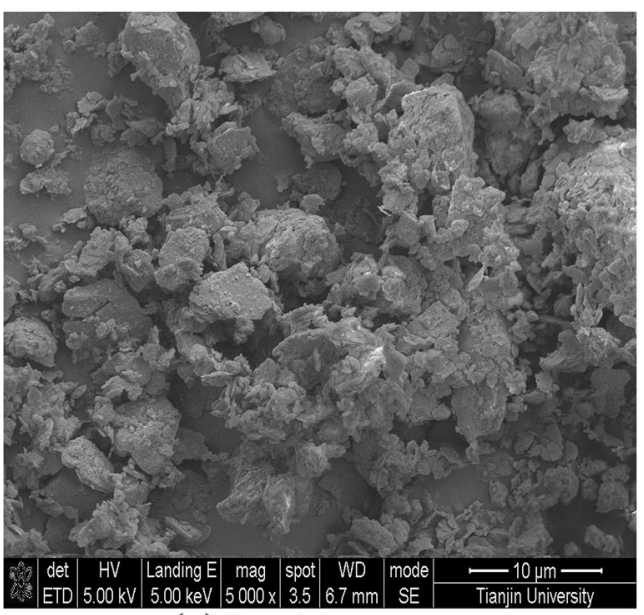

(a) Sandstone

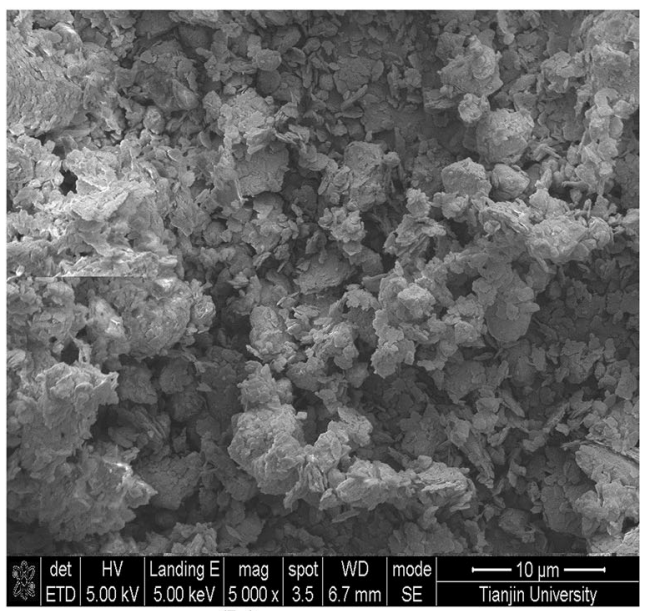

(b) Mudstone

Fig. 4 SEM morphology of rock samples in gobs

and the average pore size was $16.59 \mathrm{~nm}$, which was a mesoporous (Table 2). Compared with mudstone, the specific surface area of sandstone is obviously higher, the total pore volume is slightly higher, but the average pore diameter is opposite. Comparing the findings with those of other researchers, there is a commonality. Zhu (1996) has shown that the thickness of water-absorbing film formed by water on the pore surface of rock is different due to the difference of mineral composition, generally greater than $0.10 \mu \mathrm{m}$. Guo et al. (2016) found that the influence of rock structure is mainly manifested in the development degree of surface micro-cracks, the more the surface micro-cracks develop, the stronger the adsorption. From the results, the fallen rock in the underground mine of the coal mine in the study area can only form a water-absorbing membrane on the surface, and there is no easy flow of water inside the rock. The adsorption, filtration and sedimentation of suspended solids and other substances in the mine water are mainly located at the joints and voids formed after the stress changes in the upper strata. 


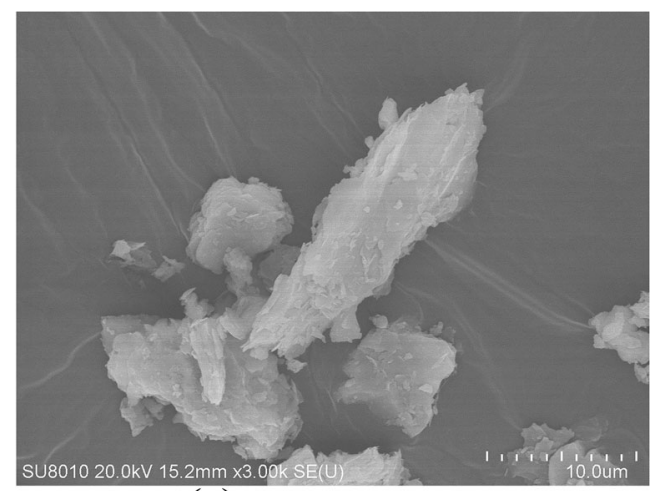

(a) Sandstone

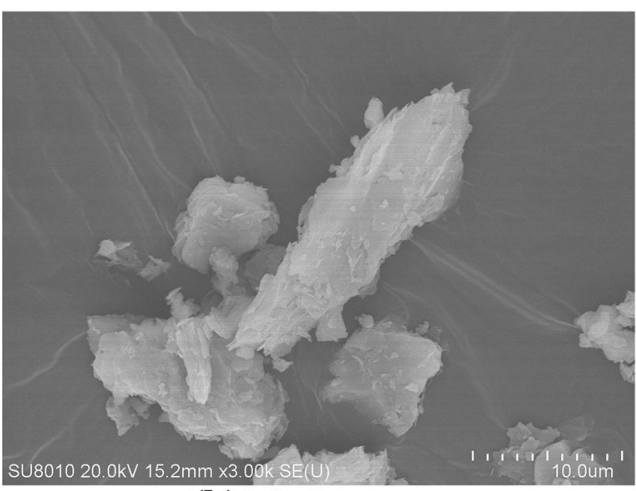

(b) Mudstone

Fig. 5 SEM morphology of rock samples after simulation experiment

Engineering practice (Gu 2012) shows that, the Daliuta coal mine's mining ratio and crack mining ratio are about 3-4:1 and 25-30:1 respectively. With the exploitation of coal, the overburden layer of the $2^{-2}$ coal seam is severely deformed, forming a large gap. The minerals in the underground reservoir of coal mine are mainly siltstones, mudstones, and their interbedded rock groups and sandstone formations. The lithology above them is also dominated by glutenite. The slump formed by siltstone and mudstone has a fine particle size and is easily muddy under the action of water, so that the particle gap becomes smaller. The latter is dominated by medium-grained sandstone and fine-grained sandstone, and part is coarsegrained sandstone, and the formed slump has a large grain size. Therefore, the particle gradation of the litter in the gob of the study area is good. The particles are arranged closely, the sandstone in the crack zone and caving zone plays a natural filtering effect. The gap between the fallen rocks and the water absorbing film formed on the surface plays a key role in water purification.

In summary, the surface structure of the mineral phase and the pores formed on the surface are the main sites for adsorption, filtration and water-rock interaction in the process of water purification, and are also the key to water purification. However, with the increase of interaction time between the fallen rock and the mine water, the surface structure of mineral phase and the pores formed on its surface will also change, so that its purification effect on mine water will slowly be weaken. Therefore, it is necessary to timely clean up the sludge deposited in the bottom of the reservoir to ensure the service life of the underground reservoir and its purification capacity.

\subsection{Analysis on the change mechanism of mineral composition in coal mine groundwater reservoir}

To further analyze the mineral composition, mudstone and sandstone samples were characterized and the results were shown in Fig. 6 and Table 3. The main minerals of the rock sample included quartz $\left(\mathrm{SiO}_{2}\right)$, kaolinite $\left(\mathrm{Al}_{2} \mathrm{O}_{3} \cdot 2 \mathrm{SiO}_{2}\right.$.

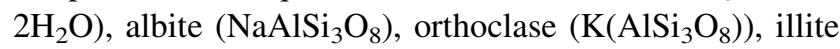
$\left(\left(\mathrm{K}, \mathrm{H}_{3} \mathrm{O}\right)(\mathrm{Al}, \mathrm{Mg}, \mathrm{Fe})_{2}(\mathrm{SiAl})_{4} \mathrm{O}_{10}\left[(\mathrm{OH}) \mathrm{H}_{2} \mathrm{O}\right]\right)$ and chlorite (Fig. 6). There are differences in the composition of the three rock samples of sandstone, mudstone, and parallel layer mudstone, but they are basically close. Among them, quartz is the most common mineral in coal-bearing rock formations, with the highest content. Kaolinite, illite, and chlorite are the main components of clay minerals. The others are also common minerals that coexist with coal (Wang et al. 2009; Liu et al. 2017; Zhang et al. 2017). In the underground reservoir of the coal mine, the average content of quartz in the sandstone was $31.40 \%$; feldspar was $44.30 \%$, which were mainly albite $\left(\mathrm{NaAlSi}_{3} \mathrm{O}_{8}\right)$ and

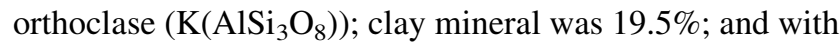
a small amount of ordinary pyroxene. The mudstone was mainly composed of clay mineral and quartz, in which the clay mineral content was about $31.3 \%$, quartz was $41.0 \%$,

Table 2 Surface structure and pore distribution of mudstone and sandstone in underground reservoir

\begin{tabular}{|c|c|c|c|c|c|c|c|c|c|}
\hline \multirow[t]{2}{*}{ Sample } & \multicolumn{3}{|c|}{ Specific surface area $\left(\mathrm{m}^{2} / \mathrm{g}\right)$} & \multicolumn{3}{|c|}{ Total pore volume $(\mathrm{cc} / \mathrm{g})$} & \multicolumn{3}{|c|}{ Average pore diameter (nm) } \\
\hline & $\begin{array}{l}\text { Multiple points } \\
\text { BET }\end{array}$ & $\begin{array}{l}\text { BJH } \\
\text { adsorption }\end{array}$ & $\begin{array}{l}\text { BJH } \\
\text { Desorption }\end{array}$ & $\begin{array}{l}\text { Single } \\
\text { point }\end{array}$ & $\begin{array}{l}\text { BJH } \\
\text { adsorption }\end{array}$ & $\begin{array}{l}\text { BJH } \\
\text { DESORPTION }\end{array}$ & $\begin{array}{l}\text { Single } \\
\text { point }\end{array}$ & $\begin{array}{l}\text { BJH } \\
\text { Adsorption }\end{array}$ & $\begin{array}{l}\text { BJH } \\
\text { Desorption }\end{array}$ \\
\hline Mudstone & 7.18 & 7.86 & 8.49 & 0.03 & 0.03 & 0.03 & 17.55 & 2.19 & 3.83 \\
\hline Sandstone & 9.93 & 11.17 & 12.05 & 0.04 & 0.04 & 0.04 & 15.62 & 2.74 & 3.81 \\
\hline
\end{tabular}




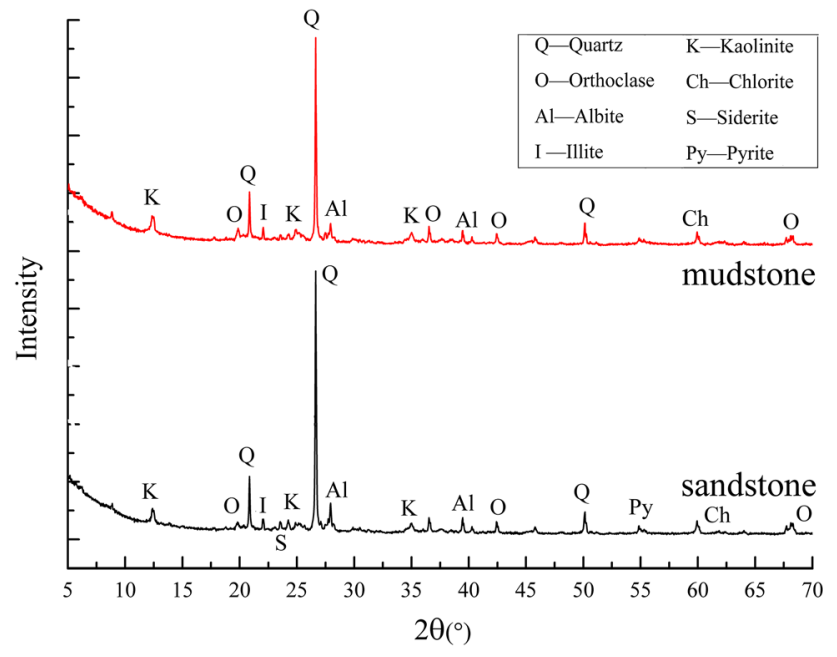

albite was $20.3 \%$, orthoclase was less, about $7.4 \%$ (Table 3). It can be seen from Fig. 7 that compared with mudstone, sandstone had less quartz, more orthoclase and less chlorite. According to the above analysis, the proportion of sandstone and mudstone is about 7:3. It can be calculated that the content of quartz is about $34.28 \%$, albite is $21.84 \%$, orthoclase is $17.48 \%$, kaolinite is $8.00 \%$. After the mine water immersion simulation experiment, it is $36.14 \%, 17.87 \%, 11.62 \%$ and $16.75 \%$, respectively; after the deionized water immersion simulation experiment, it is $35.47 \%, 19.01 \%, 14.49 \%$ and $12.46 \%$, respectively. It can be seen that when the mine water flows through the underground reservoir, the mineral composition of the fallen rock will change, which in turn will affect the water quality of the underground reservoir.

Fig. 6 Analysis of mineral composition of rock samples

Table 3 Mineral composition and content of fine sandstone (\%)

\begin{tabular}{|c|c|c|c|c|c|c|c|c|c|}
\hline Item & Rock & Quartz & Albite & Orthoclase & Kaolinite & Chlorite & Illite & Siderite & Pyrite \\
\hline \multirow[t]{2}{*}{ Original } & Sandstone & 31.40 & 22.50 & 21.80 & 8.60 & - & 10.90 & 1.20 & 3.60 \\
\hline & Mudstone & 41.00 & 20.30 & 7.40 & 6.60 & 12.00 & 12.70 & - & - \\
\hline \multirow[t]{2}{*}{ Immersion in mine water } & Sandstone & 33.80 & 17.30 & 14.20 & 20.80 & - & 10.10 & 1.00 & 2.80 \\
\hline & Mudstone & 41.60 & 19.20 & 5.60 & 7.30 & 12.30 & 14.00 & - & - \\
\hline \multirow[t]{2}{*}{ Immersion in deionized water } & Sandstone & 33.40 & 20.00 & 18.60 & 13.30 & - & 10.50 & 1.20 & 3.00 \\
\hline & Mudstone & 40.30 & 16.70 & 4.90 & 10.50 & 12.70 & 14.90 & - & - \\
\hline
\end{tabular}

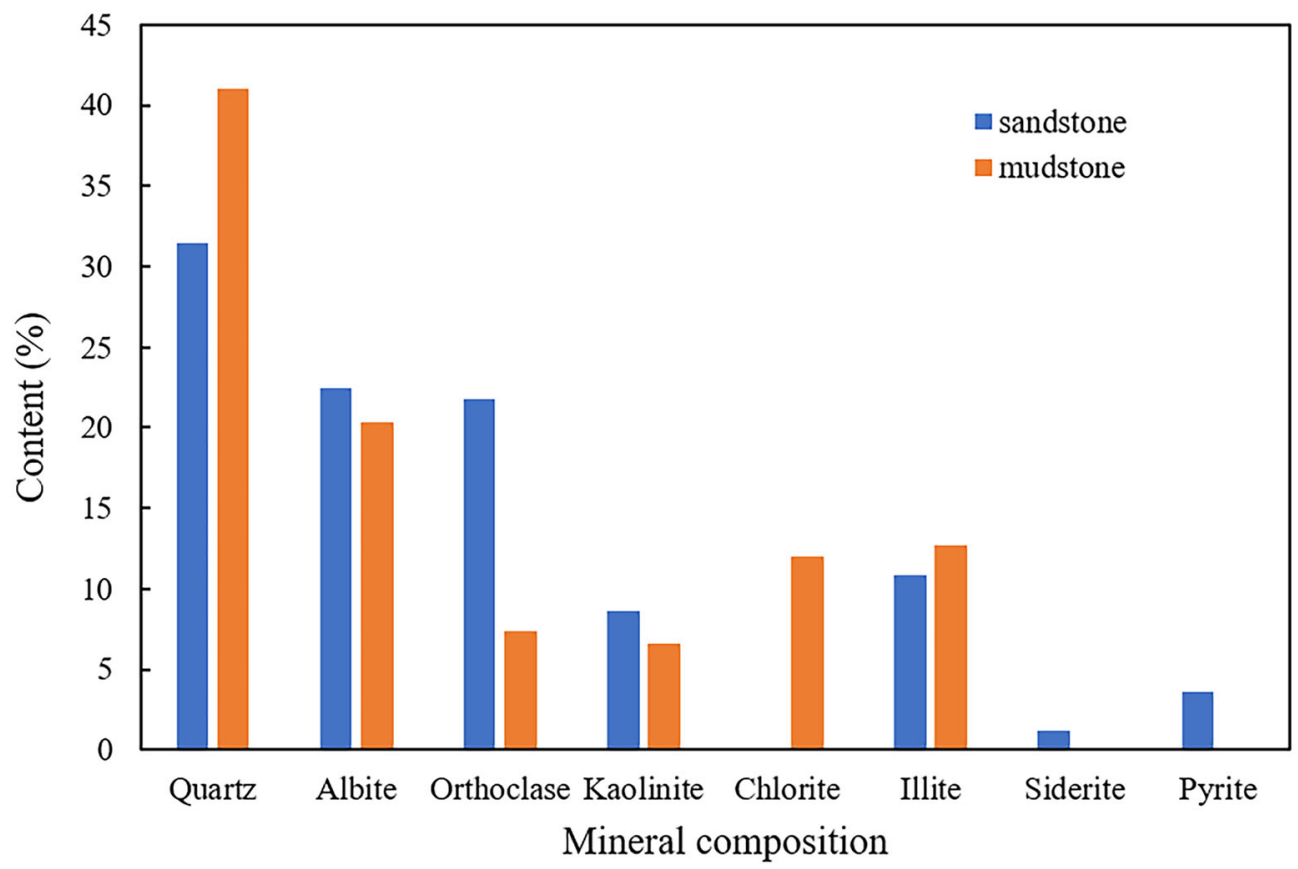

Fig. 7 Mineral composition of rock samples 
In the process of water and rock, the content of unstable minerals (calcite, dolomite, hornblende, etc.) and substable minerals (potassium feldspar, muscovite, illite, etc.) will gradually decrease, and the proportion of stable minerals (quartz, kaolinite, Oxide or hydroxide, etc.) will increase (Vincent et al. 2018; Zhang et al. 2007; Sun et al. 2012). Deionized water immersion is to study the change of minerals in rock samples in non-ionized water. Mine water immersion experiment is to study the changes of minerals in the actual underground reservoirs, and to compare and analyze the influence of mine water on rock minerals (Yan et al. 2014). Compared with the original sandstone, the content of albite and orthoclase decreased after the immersion in mine water and deionized water, kaolinite increased, illite increased slightly, and pyrite and siderite decreased slightly after soaking in mine water and deionized water (Table 3, Fig. 8). Compared with the original mudstone, the content of albite and orthoclase decreased, and kaolinite, illite and chlorite increased slightly after soaking in mine water and deionized water (Table 3, Fig. 9). The increase and decrease of the mineral content in sandstone soaked in mine water is higher than that in deionized water, while the mudstone is opposite. The change of mineral content in sandstone is more obvious than that in mudstone. It indicates that water-rock interaction occurs, such as dissolution of albite and orthoclase, kaolinite precipitation and oxidation-reduction of pyrite and siderite, and the process of water-rock interaction is related to the chemical composition of water and the composition and content of rock minerals.
The reaction patterns of different minerals and mine water are different. Feng et al. (2019a, b) studied the interaction between Gangyi spring water and stratigraphic rocks. Under the action of water and rock, calcium montmorillonite, chlorite, and illite are formed. Illite is transformed from calcium montmorillonite, and chlorite is composed of mica mineral alterations or potassium feldspar conversion. Wang et al. (2019) studied the tight sandstone kaolinite in the fourth member of the Xujiahe Formation in the western Sichuan depression. It was found that the atmospheric fresh water and coal-series acidic water caused the feldspar to dissolve in the early diagenetic stage and formed the authigenic kaolinite. With the increase of burial depth and the increase of ground temperature, some kaolinite reacted with potassium feldspar to form illite. $\mathrm{Gu}$ (2018) studied the fracturing fluid-shale interaction and found that the high content of $\mathrm{Mg}^{2+}\left(\mathrm{Ca}^{2+}\right)$ in the solution easily caused (de)dolomite formation during the reaction, and the $\mathrm{H}^{+}$produced by the oxidation of pyrite can promote the dissolution of carbonate minerals. $\mathrm{NaCl}$ solution can promote the dissolution of pyrite and inhibit the dissolution of feldspar, while $\mathrm{CaCl}_{2}$ and $\mathrm{MgCl}_{2}$ can promote the dissolution of illite and increase the precipitation of montmorillonite and chlorite.

Wandrey et al. (2011) used long-term carbon dioxide exposure experiments with fresh core materials from reservoirs. The results show that the mineral phases (nonplagioclase, potassium feldspar, anhydrite, etc.) are dissolved, which are expressed as the concentration increases of $\mathrm{Ca}^{2+}, \mathrm{Mg}^{2+}, \mathrm{K}^{+}$and $\mathrm{SO}_{4}{ }^{2-}$. The underground reservoir

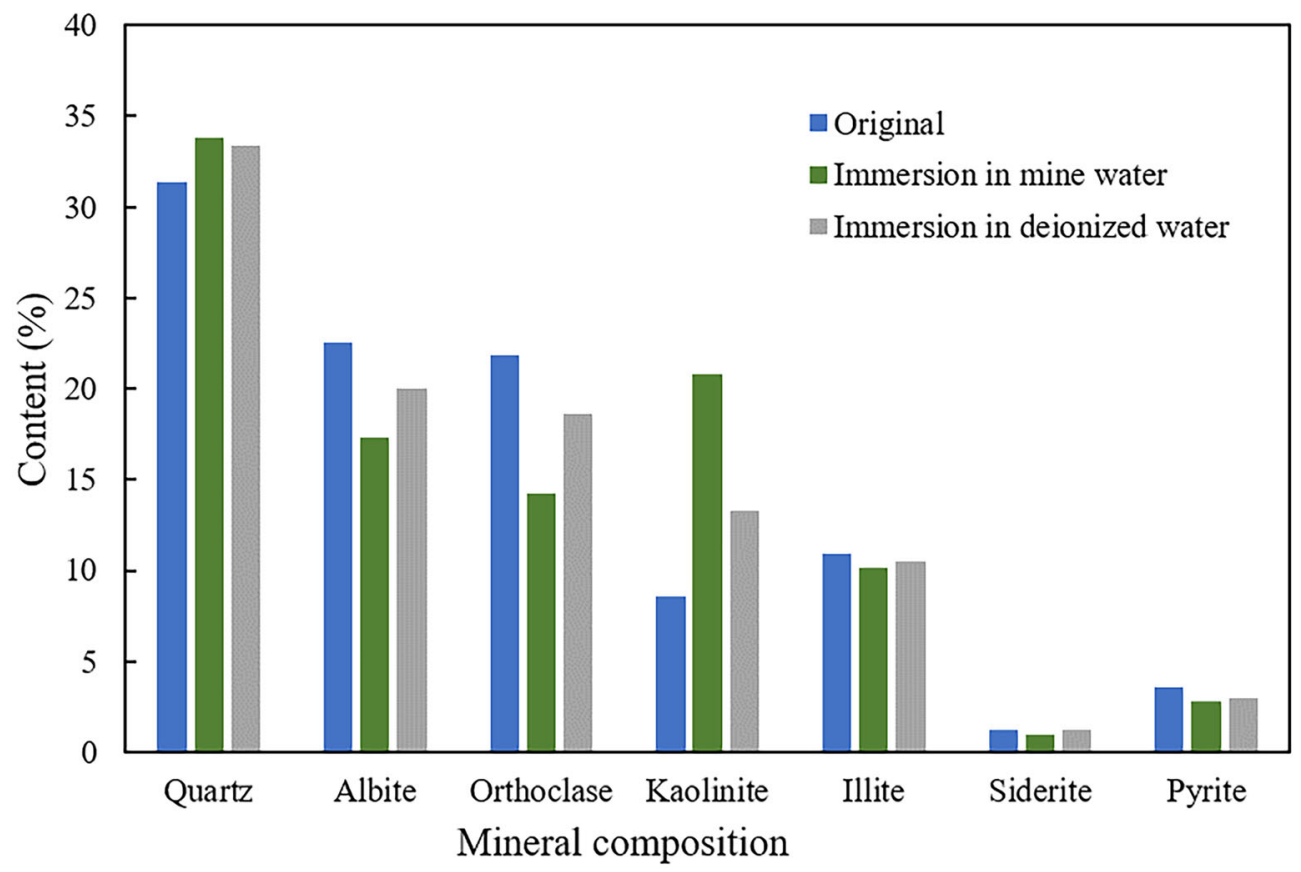

Fig. 8 The changes of mineral content in sandstone after the experiment 


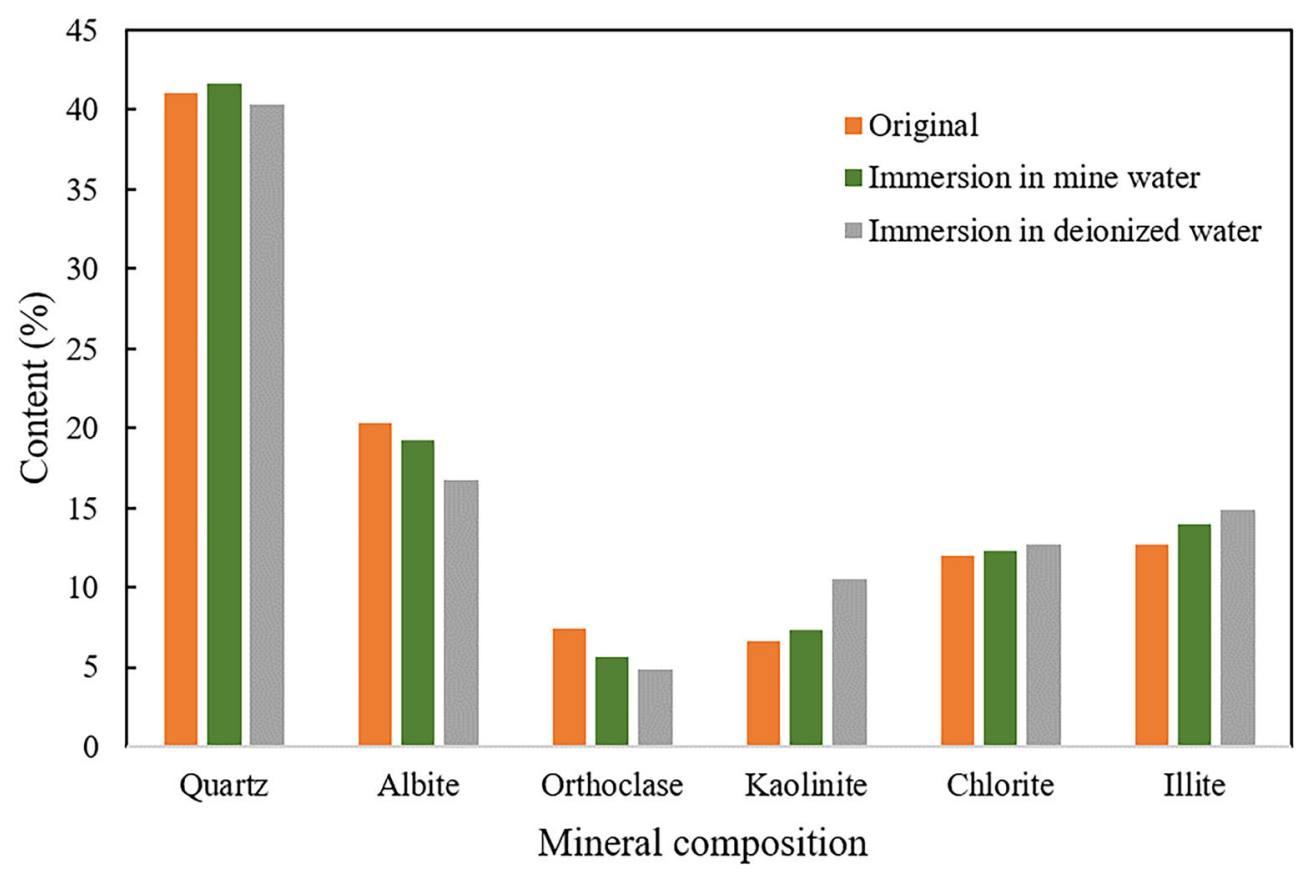

Fig. 9 The changes of mineral content in mudstone after the experiment

of the coal mine belongs to a humid semi-enclosed environment. Due to the occurrence of hydrolysis, $\mathrm{OH}^{-}$ions combine with metal cations and enter the underground reservoir of the coal mine to increase the $\mathrm{pH}$ value of the water body. $\mathrm{H}^{+}$is mainly combined with an aluminosilicate complex anion to form a poorly soluble clay mineral which is deposited on the bottom of the water. According to the previous research results, the following change process can be inferred based on the analysis of water quality in and out of the reservoir and the change of mineral characteristics with the action of water-rock. The orthoclase and albite can be dissolved at $25{ }^{\circ} \mathrm{C}$ and atmospheric pressure, and the chlorite precipitates (shown in Eq. (1)-(4)). The dissolution of silicate minerals (albite, orthoclase and illite, etc.) is the main source of $\mathrm{Na}^{+}$, and the cation exchange reaction exchanges $\mathrm{Ca}^{2+}$ and $\mathrm{Mg}^{2+}$ in water. The main reason is that when clay (or colloid) adsorbs with $\mathrm{Na}^{+}$and meet free (including freely ionizable) $\mathrm{Ca}^{2+}$, the clay mineral releases $\mathrm{Na}^{+}$and adsorbs $\mathrm{Ca}^{2+}$, which causes relative excess of $\mathrm{Na}^{+}$to $\mathrm{Cl}^{-}$and $\mathrm{Ca}^{2+}+\mathrm{Mg}^{2+}$ relative deficiency to $\mathrm{HCO}_{3}^{-}+\mathrm{SO}_{4}{ }^{2-}$ (shown in Eq. (5)-(6)). And with the extension of the reaction time, the value of sodium adsorption ratio (SAR) gradually increases, and the cation alternate adsorption between the aqueous phase and the rock phase gradually weakens. The dissolution of feldspar will produce authigenic kaolinite, and the presence of $\mathrm{K}^{+}$will cause the reaction of authigenic kaolinite to illite again (shown in Eq. (7)-(9)). $\mathrm{Mg}^{2+}$ and $\mathrm{Ca}^{2+}$ in the aqueous phase form montmorillonite, and when $\mathrm{K}^{+}$is sufficient, it is converted into illite (shown in Eq. (10)-(11)). Sulfur-containing oxides (mainly pyrite) and siderite undergo oxidation reaction, and calcium-containing magnesium oxides are neutralized (shown in Eq. (12)-(17)). These reaction formulas are presumed to be as following:

$$
\begin{aligned}
& 2 \mathrm{NaAlSi}_{3} \mathrm{O}_{8}+2 \mathrm{H}_{2} \mathrm{CO}_{3}+9 \mathrm{H}_{2} \mathrm{O} \\
& \rightarrow \mathrm{Al}_{4}\left(\mathrm{Si}_{4} \mathrm{O}_{10}\right)(\mathrm{OH})_{8}+2 \mathrm{Na}^{+}+2 \mathrm{HCO}_{3}^{-}+4 \mathrm{H}_{4} \mathrm{SiO}_{4}
\end{aligned}
$$

$4 \mathrm{KAlSi}_{3} \mathrm{O}_{8}+6 \mathrm{H}_{2} \mathrm{O} \rightarrow \mathrm{Al}\left[\mathrm{Si}_{4} \mathrm{O}_{10}\right][\mathrm{OH}]_{8}+8 \mathrm{SiO}_{2}+4 \mathrm{KOH}$

$\mathrm{CO}_{2}+\mathrm{CaCO}_{3}+\mathrm{H}_{2} \mathrm{O} \rightarrow \mathrm{Ca}^{2+}+2 \mathrm{HCO}_{3}^{-}$

$\mathrm{KAlSi}_{3} \mathrm{O}_{8}+\mathrm{Fe}^{3+}+\mathrm{Mg}^{2+}+\mathrm{H}_{2} \mathrm{O}$

$\rightarrow$ Chlorite $+\mathrm{SiO}_{2}+\mathrm{H}^{+}+\mathrm{K}^{+}$

$\mathrm{Ca}^{2+}+\mathrm{HCO}_{3}^{-}+\mathrm{Na}^{+}$(rock) $\rightarrow \mathrm{Na}^{+}+\mathrm{HCO}_{3}^{-}$ $+\mathrm{Ca}^{2+}$ (rock)

$\mathrm{Mg}^{2+}+\mathrm{HCO}_{3}^{-}+\mathrm{Na}^{+}($rock $) \rightarrow \mathrm{Na}^{+}+\mathrm{HCO}_{3}^{-}$ $+\mathrm{Mg}^{2+}($ rock $)$

$\mathrm{KAlSi}_{3} \mathrm{O}_{8}+\mathrm{H}^{+}+\mathrm{H}_{2} \mathrm{O} \rightarrow \mathrm{Al}_{2} \mathrm{Si}_{2} \mathrm{O}_{5}(\mathrm{OH})_{4}+\mathrm{SiO}_{2}+\mathrm{K}^{+}$

$\mathrm{NaAlSi}_{3} \mathrm{O}_{8}+\mathrm{H}^{+}+\mathrm{H}_{2} \mathrm{O} \rightarrow \mathrm{Al}_{2} \mathrm{Si}_{2} \mathrm{O}_{5}+\mathrm{SiO}_{2}+\mathrm{Na}^{+}$

$\mathrm{KAlSi}_{3} \mathrm{O}_{8}+\mathrm{Al}_{2} \mathrm{Si}_{2} \mathrm{O}_{5}(\mathrm{OH})_{4} \rightarrow 2 \mathrm{SiO}_{2}$ $+\mathrm{KAl}_{3} \mathrm{SiO}_{10}(\mathrm{OH})_{2}+\mathrm{H}_{2} \mathrm{O}$ 


$$
\begin{aligned}
& \text { Feldspar }+\mathrm{H}_{2} \mathrm{O}+\mathrm{Ca}^{2+}+\mathrm{H}^{+}+\mathrm{Mg}^{2+} \\
& \quad \rightarrow\left(\mathrm{K}^{+}+\mathrm{Na}^{+}\right)+\mathrm{SiO}_{2}+\text { Montmorillonite } \\
& \text { Montmorillonite }+\mathrm{K}^{+}+\mathrm{Al}^{3+} \\
& \quad \rightarrow \text { Illite }+\mathrm{Na}^{+}+\mathrm{Ca}^{2+}+\mathrm{Fe}^{3+}+\mathrm{Mg}^{2+}+\mathrm{Si}^{4+} \\
& \mathrm{FeS}_{2}+\mathrm{O}_{2}+\mathrm{H}_{2} \mathrm{O} \rightarrow \mathrm{Fe}^{2+}+\mathrm{SO}_{4}^{-}+\mathrm{H}^{+} \\
& \mathrm{FeS}_{2}+\mathrm{O}_{2}+\mathrm{H}_{2} \mathrm{O} \rightarrow \mathrm{Fe}^{3+}+\mathrm{SO}_{4}^{-}+\mathrm{H}^{+} \\
& \mathrm{FeS}_{2}+\mathrm{O}_{2}+\mathrm{H}_{2} \mathrm{O} \rightarrow \mathrm{Fe}(\mathrm{OH})_{3}(\mathrm{~s})+\mathrm{SO}_{4}^{-}+\mathrm{H}^{+} \\
& \mathrm{FeCO}_{3}+\mathrm{O}_{2}+\mathrm{H} 2 \mathrm{O} \rightarrow \mathrm{Fe}(\mathrm{OH})_{3}(\mathrm{~s})+\mathrm{H}^{+}+\mathrm{HCO}_{3}^{-} \\
& \mathrm{CaCO}_{3}+\mathrm{H}^{+} \rightarrow \mathrm{Ca}^{2+}+\mathrm{CO}_{2}(\mathrm{~g})+\mathrm{H}_{2} \mathrm{O} \\
& \left.\mathrm{MgCa} \mathrm{CO}_{3}\right)_{2}+\mathrm{H}^{+} \rightarrow \mathrm{Mg}^{2+}+\mathrm{Ca}^{2+}+\mathrm{H}_{2} \mathrm{O}+\mathrm{CO}_{2}(\mathrm{~g})
\end{aligned}
$$

In summary, the main changes in the mineral phase of the fallen rock are reflected in the dissolution of albite and orthoclase, precipitation of kaolinite, illite and quartz, and redox reaction between pyrite and siderite. The main actions of the underground reservoir in Daliuta Coal Mine are leaching, cation alternate adsorption and redox, which cause the water quality of the mine to change.

\section{Conclusions}

(1) The groundwater reservoir of Daliuta Coal Mine is dominated by sandstone, accounting for $70 \%$, and mudstone accounts for $30 \%$. Due to its composition, it is closely arranged in the groundwater reservoir, which plays a key role in the purification of water in the underground reservoir. In sandstone, feldspar has the highest content, followed by clay, and contains a small amount of pyrite and augite; while in mudstone, clay has the highest content, followed by feldspar, and contains a small amount of chlorite.

(2) Through simulation experiments, it is found that the underground reservoir of Daliuta Coal Mine mainly undergoes leaching, cation alternating adsorption, and redox. After the action of water-rock, the content of albite and orthoclase decreased, the content of kaolinite, illite, and quartz increased, and pyrite and siderite decreased slightly. Before and after the inflow of mine water, $\mathrm{Na}^{+}, \mathrm{Cl}^{-}$and $\mathrm{HCO}_{3}^{-}$ increased, and $\mathrm{Ca}^{2+}, \mathrm{Mg}^{2+}$, and $\mathrm{SO}_{4}{ }^{2-}$ decreased. The results of the simulation experiments agree with the facts in the real mine. Water-rock interaction will lead to the change of mineral surface structure and pore distribution, which will affect the subsequent purification effect of mine water. The rock adsorption capacity gradually weakens with the action of water-rock. To improve the purification ability of groundwater quality water, the groundwater reservoir should be dredged regularly.

Acknowledgements This work was co-supported by the Yue Qi Young Scholar Project, China University of Mining \& Technology, Beijing (2019QN08), National Key Research and Development Program of China (2018YFC0406404), Research on Ecological Restoration and Protection of Coal Base in Arid Eco-fragile Region (GJNY2030XDXM-19-03.2), the Fundamental Research Funds for the Central Universities (2020YJSHH12), and the scientific and technological innovation project of Shenhua Group (SHJT-16-28).

Authors' contributions Kai Zhang: experimental design and manuscript writing. Huifang Li: experimental design, data analysis and manuscript writing. Jiaming Han and Binbin Jiang: data collection. Ju Gao: Data analysis.

Funding The study and collection was supported by "China University of Mining \& Technology, Beijing and National Key Research and Development Program of China (2018YFC0406404)" and "Open Fund of State Key Laboratory of Water Resource Protection(SHJT-16-30.8)". Data analysis and interpretation was supported by "Yue Qi Young Scholar Project, China University of Mining \& Technology, Beijing" and "the Fundamental Research Funds for the Central Universities (2020YJSHH12)".

Availability of data and materials The datasets supporting the conclusions of this article are included within the article.

\section{Compliance with ethical standards}

Conflict of interest All authors have declare that they have no conflict of interest.

Open Access This article is licensed under a Creative Commons Attribution 4.0 International License, which permits use, sharing, adaptation, distribution and reproduction in any medium or format, as long as you give appropriate credit to the original author(s) and the source, provide a link to the Creative Commons licence, and indicate if changes were made. The images or other third party material in this article are included in the article's Creative Commons licence, unless indicated otherwise in a credit line to the material. If material is not included in the article's Creative Commons licence and your intended use is not permitted by statutory regulation or exceeds the permitted use, you will need to obtain permission directly from the copyright holder. To view a copy of this licence, visit http://creativecommons. org/licenses/by/4.0/.

\section{References}

Cao ZG, Li QSG, Dong BQ (2014) Water Resource Protection and Utilization Technology and Application of Coal Mining in Shendong Mining Area. Coal Eng 46(10):162-164. https://doi. org/10.11799/ce201410046

Chen SS (2016) Research on the key technology of water resources recycling utilization in the underground goaf reservoir in Shendong Mining Area. Ph.D., Dissertation, Xi' an University of Science and technology. https://kns.cnki.Net/kns/brief/ default_result.aspx

Chen SS (2018) Study on the key technologies of underground reservoir construction in coal mines. Shaanxi Coal 37(06):48-52 
Chen SS, Huang QX, Xue G et al (2016) Technology of underground reservoir construction and water resource utilization in Daliuta Coal Mine. Coal Sci Technol 44(08):21-28. https://doi.org/10. 13199/j.cnki.cst.2016.08.004

Deng HF, Zhi YY, Duan LL et al (2019) Research on the mechanical properties of sandstone and the damage evolution of microstructure under water-rock interaction. Rock Soil Mech. https://doi. org/10.16285/j.rsm.2018.1002

Du XQ, Yg L, Ye XY (2008) Study on concept, types and grades of groundwater reservoir. Chin J Undergr Space Eng 4(2):209-214

Du XQ, Lu Y, Ye XY et al (2018) Advances on porous medium clogging and water quality change during artificial recharge of groundwater. J Eng Heilongjiang Univ 9(02):1-109. https://doi. org/10.13524/j.2095-008x.2018.02.017

Feng B, Song D, Fu L et al (2019a) Formation laws of hydrothermal alteration minerals and the genesis of travertine in the Zhacang geothermal field. Guide Basin. Nat Gas Ind 158(07):133-142. https://doi.org/10.3787/j.issn.1000-0976.2019.07.018

Feng HB, Dong SG, Zhang T et al (2019b) Evolution mechanism of a groundwater system in the opencast coalmine area in the typical prairie. Hydrogeol Eng Geol 46(01):163-172. https://doi.org/10. 16030/j.cnki.Issn.1000-3665.2019.01.22

Fu XJ, Gao SB, Zheng LG et al (2018) Water chemical characteristics of coal bearing aquifer and the Taiyuan formation limestone aquifer under thrust nappe. $\mathrm{J}$ Anhui Univ Sci Technol 38(06):23-30

Goren O, Gavrieli I, Burg A et al (2011) Cation exchange and CaCO3 dissolution during artificial recharge of effluent to a calcareous sandstone aquifer. J Hydrol 400(1-2):165-175. https://doi.org/ 10.1016/j.jhydrol.2011.01.041

Gu DZ (2012) Water resource protection and utilization of coal mining in China's energy "Golden Triangle". Bei Jing, China

Gu DZ (2015) Theory framework and technological system of coal mine underground reservoir. J China Coal Soc 40(02):239-246. https://doi.org/10.13225/j.Cnki.jccs.2014.1661

$\mathrm{Gu} \mathrm{HL}$ (2018) Simulation of fluid-shale interactions during of hydraulic fracturing in shale gas exploitation. Ph.D., Dissertation, China University of Geosciences (Beijing)

Guo YL, Cao MC, Hu BL et al (2016) Micro-differences study of deep coal seam floor sandstone under water-rock interaction. Coal Technol 35(08):111-113. https://doi.org/10.13301/j.cnki.ct. 2016.08.045

Han R, Chen B, Zeng ZH et al (2016) Application of Schukalev Classification Method in discrimination of water inrush source. Inner Mongolia Coal Econ Z1:146-147

$\mathrm{Hu}$ BL, Lin XL, Jia MX et al (2016) Research of microscopic difference of deep coal seam floor mudstone based on water-rock interaction. Saf Coal Mines 47(03):31-34. https://doi.org/10. 13347/j.cnki.Mkaq.2016.03.009

Lan SS, Chi BM, Jiang JY (2010) Research to feasibility of underground reservoir construction in the medium and small coastal Basins of Northern China: taking the plain areas of Liugu River for example. Hydrogeol Eng geol 37(1):40-44. https://doi. org/10.16030/j.cnki.issn.1000-3665.2010.01.008

Li XL, Wang LG, Han L (2008) Study on of the mechanism waterrock interaction of mine water from abandoned mines during inf iltration through coal rock. J Water Resour Water Eng 05:11-14

Li QS, Ju JF, Cao ZG et al (2017) Suitability evaluation of underground reservoir technology based on the discriminant of the height of water conduction fracture zone. J China Coal soc 42(08):2116-2124. https://doi.org/10.13225/j.cnki.jccs.2016. 1871

Lin XY, Zhang WJ, He HY et al (2012) Experiment on impact of groundwater quality during artificial recharge process. J Jilin Univer 42(05):1404-1409. https://doi.org/10.13278/j.cnki.jjuese. 2012.05.026
Liu ZK (1981) Determination of carbonate and bicarbonate in mixed alkali by double mixed indicator method. J Zhengzhou Grain College 6(01):120-126

Liu F (2016) Study of water-rock interaction with hydrochemical and isotopic datum in Laizhou Bay. Compilation of academic papers of institute of geology and geophysics, Chinese academy of sciences, 2015 (15th session)-engineering geology and water resources research laboratory. Department of Science and Technology and Achievement Conversion, Institute of Geology and Geophysics, Chinese Academy of Sciences. https://kns.cnki. Net/kns/brief/default_result.aspx

Liu ZJ, Dong X, Zhang ZY et al (2017) Characteristics of clay minerals in soil profiles of Jiugong Mountain. Soils 49(04):795-802. https://doi.org/10.13758/j.cnki.tr.2017.04.023

Ma J, Wang JH (2017) Hydrochemical characteristics and ion source analysis of loose aquifer-a case study in Dingji Coalmine. J Jiamusi Univ 35(05):769-772

Ministry of Environmental Protection of the People's Republic of China (2015) Water quality-determination of 32 elementsinductively coupled plasma emission spectrometry

Ministry of Environmental Protection of the People's Republic of China (2016) Water Quality-Determination Of Inorganic Anions $\left(\mathrm{F}^{-}, \mathrm{Cl}^{-}, \mathrm{NO}^{2-}, \mathrm{Br}^{-}, \mathrm{NO}^{3-}, \mathrm{PO}^{43-}, \mathrm{SO}^{32-}, \mathrm{SO}^{42-}\right)$ - $\mathrm{Ion}$ Chromatography

Ministry of Geology and Mineral Resources of the People's Republic of China (1994) DZ/T 0064-1993 inspection methods of groundwater quality

Shen ZL, Wang YX, Guo HM (2012) Opportunities and challenges of water-rock interaction studies. Earth Sci J China Univ Geosci 37(02):207-219. https://doi.org/10.3799/dqkx.2012.021

Sun DS, Chen Y, Cao F (2012) Degradation of bauxite with complicate mineral compositions by microorganisms in culture experiments. Miner Pet 32(3):6-12. https://doi.org/10.19719/j. cnki.1001-6872.2012.03.002

Tang Q, Sheng W, Li L et al (2018) Alteration behavior of mineral structure and hazardous elements during combustion of coal from a power plant at Huainan, Anhui, China. Environ Pollut 239:768-776. https://doi.org/10.1016/j.envpol.2018.04.115

Vincent B, Waters J, Witkowski F (2018) Diagenesis of Rotliegend sandstone reservoirs (Offshore Netherlands): the origin and impact of dolomite cements. Sediment Geol 373:272-291. https://doi.org/10.1016/j.sedgeo.2018.06.012

Wandrey M, Fischer S, Zemke K et al (2011) Monitoring petrophysical, mineralogical, geochemical and microbiological effects of $\mathrm{CO}_{2}$ exposure-Results of long-term experiments under in situ conditions. Energy Procedia 4:3644-3650. https://doi.org/10. 1016/j.egypro.2011.02.295

Wang L (2017) Research and application of constitutive model of hydrous rock considering water-rock interaction. Ph.D., Dissertation, Shandong University of Science and Technology. https:// kns.cnki.Net/kns/brief/default_result.aspx

Wang XQ, Peng QL, Ma FX (2009) Contrast of coal and rock stratum for lianshao coalfield measuring water coal-bearing system. Coal Technol 28(05):137-138

Wang ZF, Hao RJ, Yang HB et al (2015) Research progress on waterrock interaction. J Water Resour Water Eng 26(03):210-216. https://doi.org/10.11705/j.issn.1672-643X.2015.03.44

Wang CR, You AJ, Shu LC (2018) Current Situation and Prospect on Groundwater Reservoir Research. Zhejiang Hydmtechnics 46(05):72-75. https://doi.org/10.13641/j.cnki.33-1162/tv.2018. 05.019

Wang YN, Lin LB, Yu Y et al (2019) Characteristics of kaolinite in tight sand reservoirs of Member 4 of Upper Triassic Xujiahe Formation in west Sichuan depression and its influence on physical properties of reservoirs. J Chengdu Univ Technol 
46(03):354-362. https://doi.org/10.3969/j.issn.1671-9727.2019. 03.10

Xu DS, Ma J, Liu XH et al (2019) Hydro-chemical characteristics and multivariate statistical analysis of groundwater in loose aquifer: a case study from Zhujidong Coalmine. J Hebei $\mathrm{N}$ Univ 35(01):17-21. https://doi.org/10.3969/j.issn.1673-1492.2019.01. 005

Yan B, Zhu SY, Yan PF et al (2014) Microcosmic mechanism discussion on action between deep lower coal group floor mudstone and water. J Coal Mine Saf 45(02):178-180. https:// doi.org/10.13347/j.cnki.mkaq.2014.02.055

Zhang QW, Chai SL, Cai J (2007) Chemical composition of groundwater from granitic areas and its constraints to the granite weathering in the Eastern of Jilin. J Jilin Univ 37(S1):171-175. https://doi.org/10.13278/j.cnki.jjuese.2007.s1.006

Zhang XQ, Lian B, Hou WG et al (2011) Corrosion of carbonate rock by artificial drainage and its potential effects to environment. Bull Min Petrol Geochem 30(03):317-327
Zhang JM, Zhang K, Yang JZ et al (2013) A method for purifying water resources of distributed underground reservoir in Coal Mine: China, CN201210473685.A[P].2013

Zhang ZW, Xu JJ, Yan HD et al (2017) Effects of elevation and lithology on clay mineral composition of soils derived from limestone. Acta Pedol Sin 54(02):535-542. https://doi.org/10. 11766/trxb201607250297

Zhang J, Yao DX, Jiang Z (2018) Study on hydrochemical characteristics and genesis of sandstone between the top and bottom of the 10 coal seam in Haizi Mine in Northern Anhui Province. J Anhui Univ Sci Technol 38(04):6-13

Zhang K, Gao J, Jiang BB et al (2019) Experimental study on the mechanism of water-rock interaction in the coal mine underground reservoir. J China Coal Soc 44(12):3760-3772

Zhu XJ (1996) The hydrological properties of soft rocks. Min Sci Technol 4(3):46-50

Zhu GL (2017) Experiment and numerical simulation study on rockwater interaction in geotechnical engineering. Ph.D., Dissertation, China University of Mining and Technology (Beijing). https://kns.cnki.Net/kns/brief/default_result.aspx 